ARTIGO ORIGINAL

OLIVEIRA, Célia Freire de ${ }^{[1]}$, BRASIL, Maria Eline Santana ${ }^{[2]}$

OLIVEIRA, Célia Freire de. BRASIL, Maria Eline Santana. Consignação dos aposentados e pensionistas: rotinas de pagamento e desconto em folha. Revista Científica Multidisciplinar Núcleo do Conhecimento. Ano 04, Ed. 05, Vol. 09, pp. 92-116. Maio de 2019. ISSN: 2448-0959

Contents

- RESUMO

- INTRODUÇÃO

- CRÉDITO CONSIGNADO

- MARGEM CONSIGNÁVEL EM FOLHA DE PAGAMENTO

- CONSIGNAÇÃO EM FOLHA DE PAGAMENTO

- CRITÉRIOS DE DESCONTOS

- ROTINAS DE PAGAMENTO EM FOLHA

- POSSIBILIDADES DE EMPRÉSTIMOS PARA OS APOSENTADOS E PENSIONISTAS

- PAGAMENTO DO DED - DEMONSTRATIVO DE EVOLUÇÃO DA DíVIDA

- DESCONTO DA RESERVA DE MARGEM CONSIGNÁVEL - RMC

- REGRAS DO CRÉDITO CONSIGNADO

- JUROS E SISTEMA DE AMORTIZAÇÃO

- MÉTODO DE AMORTIZAÇÃO PELO SISTEMA DE AMORTIZAÇÃO FRANCÊS (PRICE)

- ENDIVIDAMENTO NO CRÉDITO CONSIGNADO

- EMPRÉSTIMOS CONSIGNADOS DE APOSENTADOS E PENSIONISTAS

- METOdologia

- ANALISE DA PESQUISA

- CONSIDERAÇÕES FINAIS

- REFERÊNCIAS 
O modelo econômico atual do país vem incentivando o consumo do Crédito Consignado, que diante suas várias modalidades disponíveis no mercado financeiro, vem apresentando um crescimento contínuo desde sua implantação é impressionante, está regulado pela Lei 10.820/03, regulamentada pelos Decretos $4.840 / 03$ e 5.892/06. O presente estudo pode ser caracterizado como descritivo e bibliográfico e visa entender o que é e os dados pessoais necessários para o Crédito Consignado, também é necessário à atualização cadastral e comprovante de margem consignável do beneficiário; permitindo assim compreender que os beneficiários apresentam uma renda média de salário mínimo, e quem utiliza o Crédito Consignado compromete quase metade da sua renda mensal, pois é uma opção de crédito com parcelas descontadas em folha de pagamento. No entanto é preciso avaliar a utilização do Crédito Consignado, identificando o perfil dos seus usuários, como também, os motivos que os levam a adquirir, isso por que o Crédito Consignado tem uma das linhas de crédito com juros mais baixas do mercado, estando elas pré-fixadas, e por ser de baixo risco, existe um aumento de aposentados solicitando o Crédito Consignado, podendo ser consignado até $30 \%$ do valor da aposentadoria. Não é possível estipular exatamente o número de Beneficiários do INSS, pois alguns tipos podem ser acumulados e, portanto, o numero de benefícios emitido não correspondente exatamente ao número de pessoas beneficiadas e, também não se pode afirmar que todos esses clientes possuem renda livre de comprometimento, pois como sabemos existem inúmeras outras opções de crédito que não estão sendo observadas neste estudo.

Palavras chave: consignação, aposentados, pensionistas.

INTRODUÇÃO

O Brasil passa por uma situação financeira delicada onde muito se procura realizar empréstimos. Porém, a crise econômica atual trás outro problema que é a negativa do CPFCadastro de Pessoa Física, isso se deve a um período crítico da economia brasileira onde os cidadãos não estão dando conta de pagar suas dívidas.

Através do empréstimo consignado, aposentados e pensionistas do INSS podem pegar 
dinheiro a uma quantia menor de juros e também pagar por um período maior do que o que se utiliza em empréstimos convencionais. Esta é uma facilidade garantida pela Lei Federal $n^{\circ}$ 10.820/2003, que reforçada por aspectos abordados na Constituição Federal de 1988 traz a garantia aos aposentados e pensionistas de obter vantagens sob as outras formas de financiamentos.

Entende-se então que o empréstimo consignado é uma modalidade de crédito que vem ganhando espaço no mercado, desde que foi aprovada pelo Governo Federal. Entre suas vantagens estão às taxas mais atrativas, o desconto em folha de pagamento ou elo benefício do Instituto Nacional de Seguridade Social - INSS e a isenção de avalista, atuando nos três segmentos do mercado, setor público (funcionários públicos), privado (funcionários de empresas que oferecem o produto como mais um benefício) e INSS (aposentado e pensionista).

Também deve ser levado em conta ao analisar uma proposta de empréstimo consignado a diversidade de bancos que podem realizar este procedimento, pois são diversos.

Neste artigo ressaltarei como funciona a consignação em folha de pagamento de aposentados e pensionistas destacando a concorrência para este tipo de ação bem como seus benefícios.

O empréstimo consignado veio crescendo rapidamente nos últimos anos, depois que o aposentado ou pensionista escolhe o banco a se trabalhar, com as taxas mais baixas no mercado, o cliente precisa ter alguns documentos de identificação necessários, saber do processo operacional, desde o pedido até sua liquidação, sendo o desconto no Extrato de Consignação ou Folha de Pagamento tanto INSS, Estado ou Federal, com os prazos oferecidos de quitação entre 72 vezes (INSS) e 96 vezes (Federal ou Estadual) meses máximo.

\section{CRÉDITO CONSIGNADO}

O crédito é um termo que descreve confiança em algo ou alguém. 0 crédito, no aspecto financeiro, expressa dispor a um tomador recursos financeiros para fazer frente a despesas ou investimentos, financiar a compra de bens, entre outros. (BRASIL, 2016). 
O crédito consignado foi criado com o intuito de ampliar a oferta de crédito bancário, facilitando o acesso ao crédito em condições muito mais favoráveis, exemplo, crédito com taxas de juros menores que as normalmente aplicadas no mercado, àqueles que recebiam seus salários, remunerações, proventos e pensões, mediante folha de pagamento. Nota-se que esse desconto em folha de pagamento figura como uma garantia contratual, porque oferece à instituição financeira menor risco de inadimplência e, por representar essa garantia ao credor, configura para o devedor uma forma mais fácil e barata de concessão de crédito e propicia a cobrança de encargos mais vantajosos.

Essa sistemática se mostra vantajosa para ambas as partes, visto que na prática, obtém vantagem para a instituição financeira, que tem a segurança do recebimento da dívida, bem como "economia com o custo da análise de crédito e a própria mercantilização da concessão do empréstimo". E também enseja vantagens em prol do devedor, traduzida, de regra, em juros substancialmente menores, prazo de contratação mais alargado, podendo ocorrer parcelamentos em parcelas mínimas de quarenta e oito vezes, procedimento rápido e fácil e dispensa de outras garantias, tais como aval de terceiros. Ademais, é concedido o empréstimo aos consumidores com restrições creditícias, não sendo consultado o serviço de proteção ao crédito.

Crédito Consignado é uma modalidade de empréstimo em que o desconto da prestação mensal é feito diretamente na folha de pagamento ou de benefício previdenciário do contratante. A consignação em folha de pagamento ou de benefício depende de autorização prévia e expressa do cliente à Instituição Financeira concedente do empréstimo, é vedada a cobrança de tarifa, e quaisquer outras taxas administrativas, também é proibido o estabelecimento de prazo de carência para o início do pagamento das parcelas.

O crédito consignado é uma das linhas de crédito mais baratas do mercado, principalmente para os aposentados e pensionistas do Instituto Nacional de Seguridade Social - INSS ou funcionário público podem ter acesso ao empréstimo com facilidade. Mas é preciso cautela na hora de contratar. Para usá-lo a seu favor, fique atento ao seu funcionamento e às situações em que ele pode ser seu aliado ou inimigo.

O Crédito Consignado por ser uma das modalidades de menor custo do mercado. Em fevereiro de 2017, o saldo total de empréstimos consignados atingiu $R \$ 291,4$ bilhões, dos 
Consignação dos aposentados e pensionistas: rotinas de pagamento e

desconto em folha

quais aproximadamente $94 \%$ destinados a servidores públicos ( $R \$ 169$ bilhões) e aposentados e pensionistas do INSS (R\$ 104 bilhões).

Para os aposentados e pensionistas os juros não podem ser superiores a 2,14\% ao mês, de acordo com o art. 13, II, da Instrução Normativa da Previdência Social no 28/2008, as taxas são estabelecida para beneficiários do INSS.

Entre as normas previstas na Instrução Normativa está a obrigatoriedade das instituições financeiras informarem previamente ao titular do benefício, no ato da contratação de empréstimos, o valor total financiado, a taxa mensal e anual de juros, acréscimos remuneratórios, moratórios e tributários, o valor, número e periodicidade das prestações e a soma total a pagar por empréstimo. Ao assinar o contrato, o beneficiário deverá exigir sua via.

MARGEM CONSIGNÁVEL EM FOLHA DE PAGAMENTO

Para fazer um consignado é preciso ter margem disponível. E você consegue checar isso quando tira o Extrato de Pagamentos, pois ele mostra se existem outras dívidas saindo do benefício ou da aposentadoria que você recebe.

A Margem é o valor máximo que pode ser descontado todos os meses do benefício para pagar um empréstimo. Então, se você já tem outros consignados, sua Margem fica menor e você não consegue emprestar tanto dinheiro, podendo ter o crédito recusado.

A Margem Consignável é o limite ao qual se pode comprometer da renda. Somam-se todas as rendas fixas do cliente e subtraem os descontos fixos, o resultado desta conta se multiplica por $30 \%$ em casos de empréstimos e $5 \%$ quando existe a possibilidade de cartões pelo convênio. Ou seja, você pode solicitar um empréstimo consignado de $30 \%$ da sua renda ou benefício e, caso seja necessário utilizar os 35\% total - com a ressalva que esses $5 \%$ só podem ser via cartão consignado.

A primeira informação que deve ser analisada no Extrato de Pagamento é a "Competência", nela terá o período ao qual foi gerada a informação, isto é importante porque no caso do INSS temos uma defasagem de quase 30 dias, ou seja, caso tenha realizado algum 
Consignação dos aposentados e pensionistas: rotinas de pagamento e

desconto em folha

empréstimo após o fechamento da folha que geralmente ocorre entre a segunda ou terceira semana do mês, pode não conseguir visualizar a parcela contratada e calcular errado, nesse seu caso, calcule considerando a parcela, mesmo que ela não esteja aparecendo em seu detalhamento.

Algumas modalidades de empréstimo quando associadas ao seu benefício podem não aparecer em seu Detalhamento, mas o fato de terem sido informadas ao INSS deverá ser calculado, chamada de "Parcela Oculta", geralmente empréstimos em caixa eletrônicos ou em bancos, estes tipos de empréstimos podem interferir em sua margem de empréstimo consignado.

\section{PREVIDENCIA SOCTAR}

\section{Extrato de Pagamentos}

Detalhamento de Crédito

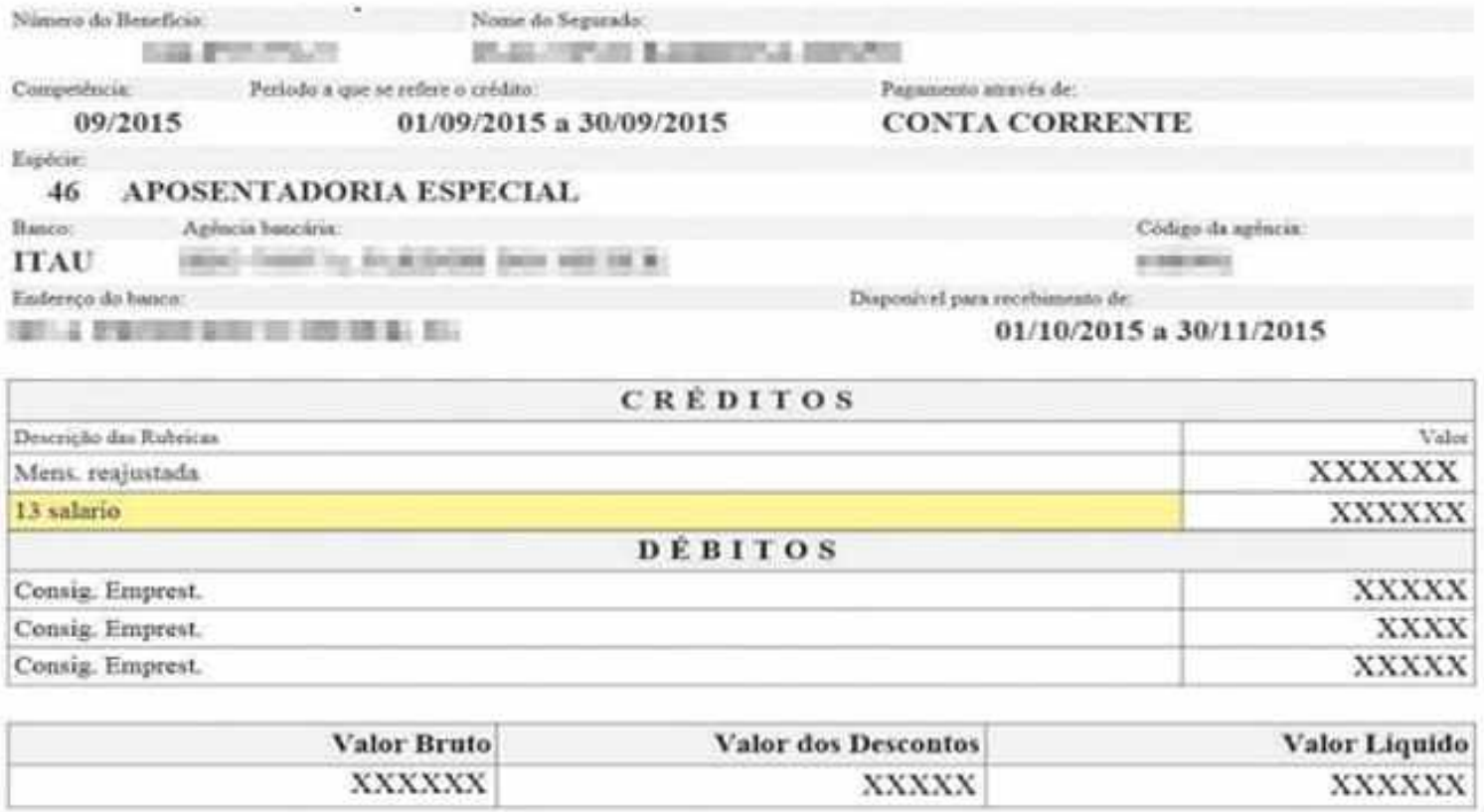

Este extrato vale para simples conferéncia

A utilização da Margem de Consignação faz com que o assédio das instituições financeiras 
aumente devido ter acesso a informações dos aposentados e pensionistas por meio de sistemas internos de consultas. Observar-se que na medida em que aumenta a utilização da Margem Consignável, mais os aposentados e pensionistas dizem ser contatados por instituições financeiras para fazer novo empréstimo.

\section{CONSIGNAÇÃO EM FOLHA DE PAGAMENTO}

A contribuição para o Instituto Nacional do Seguro Social dá acesso a diversos direitos, como a aposentadoria, auxílio-doença, 13오a salrio, pensão por morte, entre outros benefícios, para aqueles que estejam segurados pelos auxílios.

Consignação é o ato pelo qual se faz o desconto de determinada importância na folha mensal de pagamento do servidor público estadual e militar, ativo e inativo e pensionista devido a obrigações contraídas com a Administração Pública ou terceiros habilitados. As consignações somente poderão ser incluídas na folha de pagamento após a autorização expressa do consignado.

A consignação divide-se em:

1) Descontos obrigatórios ou compulsórios: são descontos aplicados por força de legislação, exemplo:

- Por força de Lei: contribuição ao plano de seguridade social - PSS, impostos;

- Por mandado judicial: pensões alimentícias, reposição ao erário, etc.;

- Por decisão administrativa: faltas, suspensões, reposição ao erário;

- Contribuição para sindicato ou associação sindical, dentre outros.

2) Descontos facultativos: desconto incidente sobre a remuneração, subsídio ou provento mediante a autorização prévia e formal do interessado, tais como:

- Contribuição para serviço de saúde prestado diretamente por órgão público federal, ou para plano de saúde prestado mediante celebração de convênio ou contrato com a União, por operadora ou entidade aberta ou fechada; 
Consignação dos aposentados e pensionistas: rotinas de pagamento e

desconto em folha

- Pensão alimentícia voluntária, consignada em favor de dependente indicado no assentamento funcional do servidor;

Contribuição em favor de fundação instituída com a finalidade de prestação de serviços a servidores públicos ou em favor de associação constituída exclusivamente por servidores públicos ativo, inativo ou pensionista e que tenha por objeto social a representação ou prestação de serviços a seus membros; (Redação dada pelo Decreto no 6.574, de 2008).

- Prestação referente a empréstimo concedido por cooperativas de crédito constituídas, na forma da lei, com a finalidade de prestar serviços financeiros a seus cooperados; (Redação dada pelo Decreto no 6.574 , de 2008).

- Prestação referente a empréstimo ou financiamento concedido por entidades bancárias, caixas econômicas ou entidades integrantes do Sistema Financeiro da Habitação; e (Redação dada pelo Decreto no 6.574, de 2008).

- Prestação referente a empréstimo ou financiamento concedido por entidade aberta ou fechada de previdência privada.

A Consignação só será processada na Folha de Pagamento se suportadas pelo total dos rendimentos do aposentado/pensionista. De acordo com o Instituto Nacional de Seguridade Social - INSS, o número de prestações do empréstimo não pode passar de 72 (setenta e dois) mensais e sucessivas. A taxa de juros também não poderá ser superior a 2,14\% ao mês.

\section{CRITÉRIOS DE DESCONTOS}

Inicialmente o desconto em folha de empréstimos, financiamentos e operações de arrendamento, mercantil, possibilitado pela CLT, passou a ser regulado pela MP 130, de 17.09.03. O recolhimento mensal dos valores previstos, de acordo com o Instituto Nacional de Seguridade Social - INSS, o número de prestações do empréstimo não pode passar de 72 vezes - mensais e sucessivas, referente à contratação de créditos consignados em folha de pagamento.

No crédito consignado o aposentado ou pensionista recebe o dinheiro agora para pagar em 
parcelas, assim como em um empréstimo pessoal comum. A diferença é que as parcelas são descontadas automaticamente do seu benefício, seja ele aposentadoria ou pensão do INSS. Ou seja, antes mesmo de você receber o pagamento da aposentadoria ou pensão do Instituto Nacional de Seguridade Social - INSS, o banco já faz o desconto. Assim, enquanto ainda estiver pagando as parcelas do empréstimo consignado, o valor que você vai receber será menor.

Quando aposentados e pensionistas do Instituto Nacional de Seguridade Social - INSS procuram por um crédito consignado, o empréstimo é calculado com base no valor da aposentadoria ou pensão que eles recebem. Além disso, os bancos e financeiras costumam oferecer condições interessantes para pessoas nestas condições, pois o consignado dá a eles uma garantia de que o empréstimo será quitado. Assim, eles conseguem oferecer taxas de juros menores e prazos de pagamento maiores, podendo chegar a até 72 meses (seis anos).

O INSS limita a taxa máxima de juros que podem ser cobradas pelos bancos conveniados, de acordo com Diário Oficial da União de 23/Mai/2012 o INSS determina que a taxa máxima que pode ser cobrada pelas 44 instituições financeiras que operam com o consignado para o INSS é de $2,14 \%$ a.m. e para o cartão de crédito 3,06\% a.m.; vale salientar que essa taxa vem sendo reduzida no decorrer dos anos.

É vedada pelo INSS qualquer cobrança de Taxa de Abertura de Crédito - TAC aos beneficiários desde maio de 2006.

\section{ROTINAS DE PAGAMENTO EM FOLHA}

O desconto no valor da aposentadoria e pensão por morte pagas pela Previdência Social das parcelas referentes ao pagamento de empréstimo pessoal e cartão de crédito, concedidos por instituições financeiras, obedecerão ao disposto na Instrução Normativa INSS/PRES no 28, de 16/05/2008 (DOU de 19/05/2008).

Sempre que o Beneficiário receber o benefício por meio de crédito em conta corrente, o crédito do empréstimo concedido deverá ser feito, obrigatoriamente, nessa conta, constituindo motivo de recusado pedido de consignação a falta de indicação da conta ou indicação de conta que não corresponda àquela pela qual o beneficio é pago. 
Confirmado o efetivo registro da consignação pela INSS, a instituição financeira obriga-se a liberar o valor contratado ao beneficiário no prazo máximo de 48 horas, contadas da confirmação.

Benefício Recebido em:

- Conta Corrente bancária do Beneficiário contratante, pela qual recebe o benefício previdenciário, sempre que esta seja a modalidade pela qual o benefício é pago;

- Cartão Magnético: para os beneficiários que recebem seus benefícios na modalidade de Cartão Magnético, o depósito deverá ser feito em Conta Corrente ou Poupança, expressamente designada pelo titular do benefício e que ele seja o responsável ou por meio de Ordem de Pagamento, preferencialmente na agência/banco onde ele recebe o seu benefício mensalmente. Outras formas:

- Ordem de Pagamento (OP): uma das possibilidades quando o cliente recebe por Cartão Magnético e não tem Conta em seu próprio nome, com valores mínimos e máximos estipulados pelos bancos.

- Vale Postal (VPE): outra possibilidade é quando o cliente recebe por cartão magnético e não tem conta em seu próprio nome, e a cidade que esta não tem agências bancárias correspondentes, então é feito Vale Postal, nas agências dos Correios.

- Para OP e VPE, o prazo máximo para saque é de 15 (quinze) dias corridos. Saque somente na agência informada na proposta.

Alguns bancos Não permitem OP ou VPE para Clientes não alfabetizados.

- Valor é limitado por CPF.

POSSIBILIDADES DE EMPRÉSTIMOS PARA OS APOSENTADOS E PENSIONISTAS

Muitos clientes quando não tem margem consignável e ficam aflitos, mas existem possibilidades para estes casos. Destacamos: 
Consignação dos aposentados e pensionistas: rotinas de pagamento e

desconto em folha

- Margem Complementar de Empréstimo Consignado

A Margem Complementar é uma das melhores formas do Aposentado ou Pensionista conseguirem aumentar seu limite de crédito, isso acontece com o aumento salarial:

- Agregar margem no Refinanciamento;

- Empréstimos Novos;

- Limite do seu cartão de crédito Consignado.

Agregação da Margem Complementar:

A agregação de Margem também é um forte aliado para aqueles casos aonde já se excedeu a quantidade de contratos, ou que tenha pagado menos de $30 \%$ para poder refinanciar.

- Refinanciamento

Nada mais é que renegociar o que se foi pago, voltando o contrato para o inicio e liberando o saldo para o cliente como um novo empréstimo. Atualmente só é possível fazer o Refinanciamento tendo pagado pelo menos $30 \%$ do prazo do contrato. 0 refinanciamento é a melhor forma de você não aumentar seu comprometimento mensal, e muitos clientes quando se deparam com uma situação de necessitar de um empréstimo muitas vezes acabam assumindo mais uma parcela, já no refinanciamento isso não acontece, pois você utiliza a mesma parcela que já está pagando.

O refinanciamento do crédito consignado é calculado de acordo com o saldo devedor da dívida inicial:

Valor do contrato consignado - Saldo devedor = Limite de crédito concedido no refinanciamento.

Portanto, quanto mais parcelas do empréstimo consignado você já tiver pagado, menor será o saldo devedor e, consequentemente, maior será o crédito que poderá ser concedido no refinanciamento.

Outra vantagem de optar pelo refinanciamento de um empréstimo é não ter que aumentar seu comprometimento financeiro mensal contraindo uma nova dívida (ampliando apenas o 
Consignação dos aposentados e pensionistas: rotinas de pagamento e desconto em folha

prazo de pagamento/número de parcelas, devido ao refinanciamento).

- Portabilidade

Segue a mesma lógica do Refinanciamento, contudo a operação é feita entre Bancos, ou seja, a possibilidade de trocar a dívida de um banco para outro. Muitas vezes o cliente se beneficia da portabilidade por uma taxa de juros menor o que possibilita um valor liberado maior.

O aposentado ou pensionista pesquisar em diversas instituições financeiras condições melhores para quitação de uma dívida existente como o seu empréstimo consignado

Escolhida uma nova instituição financeira, passa-se à negociação. Cabendo à instituição a avaliação do perfil do consumidor e a decisão sobre a aceitação da portabilidade.

Caso a nova instituição financeira aceite à portabilidade, é a própria instituição que deverá fazer o pedido de portabilidade ao banco de origem, enviando um formulário com sua proposta.

O banco de origem, onde foi contratada a dívida, tem um prazo de cinco dias para apresentar uma contraproposta à nova instituição financeira. Se a contraproposta não for feita dentro do prazo ou não for aceita pelo consumidor, a portabilidade é feita automaticamente.

A nova instituição financeira paga, ela mesma, a dívida ao banco de origem, por meio eletrônico, e o consumidor passa a dever apenas para essa nova instituição.

Passo a passo Portabilidade

A portabilidade consiste em cinco etapas: 
- Solicitação do DED - Demonstrativo de Evolução da Dívida (Boleto eletrônico solicitado pelo banco que está portando seu contrato).

- Pagamento do DED - Demonstrativo de Evolução da Dívida e conciliação por parte do banco portado.

- Baixa do Contrato

- Inclusão do Contrato

- Refinanciamento

É importante entender que para cada etapa existem prazos a serem percorridos e critérios a serem atendidos.

Ao solicitar uma portabilidade o primeiro passo é realizado pelo banco que está portando a sua dívida. Funciona da seguinte maneira:

- Solicita-se um boleto para a quitação da dívida e é recolhido uma taxa para efeito de compensação ao banco portado.

- Esta taxa recolhida fica a cargo do banco que estiver portando não podendo ser repassado ao cliente.

- O Banco portado tem 05 (cinco) dias úteis para emitir o DED - Demonstrativo de Evolução da Dívida

- O Banco portado tenta durante os 05 (cinco) dias úteis convencerem o cliente a permanecer no banco.

Muitas vezes este prazo de 05 (cinco) dias úteis extrapola porque a primeira tentativa do banco portado é desqualificar a operação alegando que existem erros no dado da operação, isso ocorre porque ao solicitar o DED - Demonstrativo de Evolução da Dívida é necessário informar, número de contrato, prazo inicial e final, além de outras informações.

\section{PAGAMENTO DO DED - DEMONSTRATIVO DE EVOLUÇÃO DA DÍVIDA}

O pagamento do DED - Demonstrativo de Evolução da Dívida é realizado pelo Banco que estiver portando sua dívida e ao fazê-la leva em torno de 48 horas para o banco que foi portado enxergar o pagamento e iniciar o processo de baixa junto ao seu convênio.

Na prática leva às 48 horas mesmo, pode acreditar! Mesmo por debaixo dos panos existirem um entendimento que em menos de duas horas com boa vontade já se conseguiria acusar 0 pagamento.

Existem instituições que fazem questão de não enxergar mesmo após as 48 horas, mas ai 
neste caso, o seu querido agente de crédito, correspondente e até o banco tem que implorar para baixar no sistema do banco portado.

Feito o pagamento e o banco portado finalmente enxergado, se dá inicio a baixa do seu contrato, o que dependendo do convênio pode levar até 07 (sete) dias úteis.

Finalmente dado à baixa do contrato o banco que portou faz a inclusão do seu contrato com as mesmas condições que estava no banco anterior, ou seja, se a parcela era de R\$100,00 e já tinha pagado 36 de 72x, seu contrato vai para o banco que está portado com as mesmas condições.

Uma vez portado só libera crédito para o cliente refinanciando este contrato, aonde voltaria para o prazo máximo permanecendo o mesmo valor de parcela, ou seja, utilizando o exemplo acima, se contrato portado com parcela de $\mathrm{R} \$ 100,00 \mathrm{com} 36$ de $72 x$ pagas, ficaria com 0 mesmo valor de parcela de $\mathrm{R} \$ 100,00$, porém com 0x (zero) de 72 parcelas pagas.

A portabilidade reduz juros sim, na maioria das vezes, mas estamos falando em redução, por exemplo, de $2,3 \%$ para $2,14 \%$ ou $1,9 \%$, e varia muito, mas na prática o que o cliente recebe de troco não é tão diferente de se refinanciar seu contrato no Banco Atual.

A portabilidade é muito bacana em situações que a politica de crédito do banco não lhe atende mais, ou que seu contrato é antigo e celebrado em taxas superiores a 2,3\%.

- Cartões

Recentemente foi liberada pelo governo a possibilidade de utilizar $5 \%$ de margem para 0 limite de um cartão de crédito. Como a taxa de juros do cartão de crédito consignado é muito baixa, muitos clientes tem sacado este limite em dinheiro e pagando apenas o mínimo do cartão que já vem descontado em folha, ou ele também tem a possibilidade de usar ele somente com o limite para crédito, sem sacar. O pagamento mínimo deste cartão amortiza o saldo devedor e vira uma espécie de "empréstimo".

Algumas regras:

- O cartão de crédito é concedido apenas quando o beneficiário solicita. É preciso ter um 
Consignação dos aposentados e pensionistas: rotinas de pagamento e

desconto em folha

contrato formal assinado ou ser autorizado eletronicamente, com uso de cartão magnético e senha eletrônica.

- O beneficiário precisa autorizar formalmente a consignação do seu empréstimo no pagamento do benefício.

- Não pode ser emitido cartão de crédito adicional ou derivado do titular, bem como é vedada a cobrança de taxa de manutenção ou anuidade.

- O limite de gastos do cartão de crédito é de até duas vezes o valor da renda mensal do benefício.

- As parcelas mensais não podem ultrapassar $10 \%$ do valor da renda líquida mensal do beneficiário.

- Serão cobrados juros se for feito o pagamento do valor mínimo, optando pelo crédito rotativo.

- O titular do cartão que quitar a fatura em uma única parcela não pagará juros. Cuidado ao usar o cartão de crédito e o empréstimo consignado.

Lembre-se de que o crédito só é fácil quando você pode pagar.

- A taxa de juros efetiva é de até 3,5\% ao mês.

- Retenção

Esta modalidade é a retenção, instituída pela Lei 10.953 de 2004. Nesta operação o INSS repassa o valor integral do benefício para a instituição financeira pagadora do benefício, que retém o valor do desconto. Esta modalidade pode ocorrer exclusivamente com os respectivos bancos pagadores dos benefícios previdenciários.

O empréstimo por meio de retenção, nada mais é que o próprio banco onde o aposentado ou pensionista recebe o beneficio, ou seja, a própria instituição faz o desconto da parcela acordada. 
Consignação dos aposentados e pensionistas: rotinas de pagamento e

desconto em folha

Nesta modalidade, os contratantes que no caso são só beneficiários do INSS, contratam o próprio banco onde os mesmo recebem os benefícios.

Não se faz necessário contratar outro banco, ou outra financeira para contratar o empréstimo.

O próprio INSS repassa o valor integral do beneficio ao banco contratado e este por sua vez faz a retenção/ faz o desconto do valor devido.

O que é bom nesta modalidade de empréstimo é o relacionamento que muitas vezes o beneficiário já tem para com o banco pagador, ou seja, já são clientes e muitos de longa data e ser o mesmo local físico.

O que deve ser observado pelo contratante, é que ele não consegue verificar este desconto caso seja necessário, no detalhamento de crédito e sim apenas no extrato da conta corrente/poupança.

\section{DESCONTO DA RESERVA DE MARGEM CONSIGNÁVEL - RMC}

Alguns aposentados e pensionistas do INSS possuem um desconto no seu Extrato de Pagamento com a sigla RMC - Reserva de Margem Consignável, é o Cartão INSS de crédito para aposentados e pensionistas do INSS (Instituto Nacional do Seguro Social) é um produto financeiro disponível na maioria dos bancos que fazem Crédito Consignado. Assim como os empréstimos na folha, o Cartão de Crédito INSS também é descontado em folha de pagamento em todas as compras efetuadas com ele, o beneficiário, ao constituir a Reserva de Margem Consignável- RMC, não poderá ser onerado com a cobrança de qualquer custo adicional de manutenção ou anuidade, excetuando o previsto nesta Instrução Normativa, de forma que a taxa de juros expresse o custo efetivo do cartão de crédito.

Com o Cartão INSS Consignado, os beneficiários podem comprometer até $10 \%$ da renda com empréstimo por meio desta consignação. Mas preste atenção no seu Detalhamento de crédito, ao solicitar o cartão às instituições financeiras mesmo sem 0 aposentado ou pensionista realizar saques ou compras pedem a reserva de margem de $10 \%$ do beneficio para o INSS restando somente $20 \%$ para empréstimos em dinheiro. Assim como os 
empréstimos na folha, o Cartão de Crédito Instituto Nacional de Seguridade Social - INSS também é descontado em folha de pagamento todas as compras efetuadas com ele.

\section{REGRAS DO CRÉDITO CONSIGNADO}

Somente Instituições Financeiras conveniadas com o Instituto Nacional de Seguridade Social - INSS podem oferecer essa modalidade de crédito consignado. As condições em que os aposentados e pensionistas podem tomar esse crédito são regulamentadas pelo INSS através de Instruções Normativas. Na época em que este estudo estava sendo escrito, houve uma alteração nas condições de empréstimo consignado do INSS.

Com o empréstimo consignado, além de ter valores bem mais atrativos para os segurados do Instituto Nacional de Seguridade Social - INSS no tocante às taxas, os valores já serão descontados da folha de pagamento do INSS, o que facilita tanto o pagamento como o recebimento desses valores.

As Regras dos Empréstimos Consignados do Instituto Nacional de Seguridade Social - INSS dizem que os aposentados e pensionistas, por passarem a ter mais tempo para a quitação do empréstimo, acabam pagando em parcelas menores. Mas nem tudo é perfeito, pois o juro não diminui, ficando maior no valor final do pagamento. Essas regras beneficiam os bancos já que o crédito deles tornou-se mais atrativos assim.

Para as operações feitas com cartão de crédito, que contam com juro máximo de 3,60\% mensais, com as novas regras poderá ser concedido o limite de $10 \%$ do valor do benefício. Esse percentual ficará restrito a movimentação de, no máximo, três vezes o rendimento do aposentado.

As regras dos Empréstimos Consignados do Instituto Nacional de Seguridade Social - INSS, segundo Carlos Eduardo Gabas, ministro interino da Previdência Social, têm o objetivo de controlar o endividamento dos aposentados perante os empréstimos com o Instituto Nacional de Seguridade Social - INSS, além de atender aos pedidos das entidades que representam a classe.

Com a mudança os aposentados pelo Instituto Nacional de Seguridade Social - INSS tem um 
aumento na restrição para contratar uma segunda operação depois de pedir a anulação da primeira por alegação de golpes ou fraude. Agora pelas novas regras, o aposentado do INSS ou pensionista que alegar fraude não vai ter o direito de comprometer novamente os $30 \%$ do benefício. Isso vai impedir que a soma dos empréstimos ultrapassasse esse percentual da renda. Nos casos em que a primeira operação comprometeu $20 \%$ do benefício, o teto da segunda será apenas de 10\%.

\section{JUROS E SISTEMA DE AMORTIZAÇÃO}

De uma forma simples pode-se entender juros como a remuneração sobre o capital, sendo o regime de amortização determinante para a forma de acumulação dos juros. Conforme Castanheira e Macedo (2008, p. 14), "é a remuneração do capital emprestado, podendo ser entendido como o aluguel pago pelo uso do dinheiro". Os juros praticados nos créditos concedidos por instituições financeiras são juros compostos, ou seja, incidem sobre o capital mais o juro acumulado anteriormente.

Após a efetivação do empréstimo, o valor financiado pode ser devolvido por meio de amortização em parcelas ou pagamento único. No caso específico do crédito consignado, em que todas as prestações têm o mesmo valor, é utilizado o sistema de amortização francês, ou Sistema Price.

Os juros cobrados têm seu teto definido de acordo com o Sistema Especial de Liquidação e de Custódia (taxa Selic), que é a taxa básica de juros no Brasil. Esta taxa é utilizada pelo Banco Central para atingir as metas estabelecidas pelo Comitê de Política Monetária Copom.

A taxa Selic é uma ferramenta do Governo Federal para controlar a inflação que, de acordo com Sandroni (1999), é o aumento persistente dos preços em geral, do que resulta uma contínua perda de poder aquisitivo da moeda.

De acordo com a recente Resolução do Conselho Nacional de Previdência - CNP a queda na taxa básica de juros (Selic) nos últimos meses, o Conselho Nacional de Previdência (CNP) aprovou a redução do teto dos juros cobrados nas operações de crédito consignado para aposentados e pensionistas do Instituto Nacional do Seguro Social (INSS). 
Consignação dos aposentados e pensionistas: rotinas de pagamento e

desconto em folha

Ao mês, o percentual do empréstimo consignado cai de 2,14\% para 2,08\%. Ocorreu também redução para operações realizadas pelo cartão de crédito, cuja taxa passa de 3,06\% para 3\% ao mês.

MÉTODO DE AMORTIZAÇÃO PELO SISTEMA DE AMORTIZAÇÃO FRANCÊS (PRICE)

A chamada Tabela Price é um método de amortização em que as parcelas devidas, embora fixe no período, estão calculadas pelo sistema de amortização constante de série uniforme.

Nesse método de amortização, as parcelas são iguais e os juros incidem sobre o saldo devedor e, à medida que as parcelas são pagas: a) as quotas de amortização do capital aumentam; b) os saldos devedores diminuem; c) as quotas de pagamento de juro diminuem. Assim, no final do prazo estipulado, a dívida se reduz a zero (MOREIRA, 1967).

Conforme Dal Ri (2009) para se obter o valor das parcelas constantes ao longo do período de financiamento, a base utilizada para esse cálculo é a formuladas séries uniformes de amortização, que assim se apresenta:

$$
V A \text { ou } P V=P M T \cdot \frac{(1+i)^{n}-1}{i(1+i)^{n}}
$$

Fonte: Dal Ri (2009)

Onde:

_ VA ou PV = valor da dívida financiada

_ PMT = a parcela constante a serem paga onde os juros cobrados já estão embutidos neste valor 
Consignação dos aposentados e pensionistas: rotinas de pagamento e desconto em folha

_ i = taxa de juros cobrados por período de amortização

_ $\mathrm{n}=0$ prazo a ser amortizado.

O sistema de amortização Price, portanto, é o método utilizado pelas instituições financeiras para calcular o retorno do valor emprestado na modalidade crédito consignado aos clientes beneficiários do INSS.

\section{ENDIVIDAMENTO NO CRÉDITO CONSIGNADO}

O endividamento é o resultado do acúmulo de dívidas, e pode ser originado por múltiplos fatores, tais como: situações econômicas, sociais, culturais e emocionais, que podem contribuir para o descontrole das finanças pessoais e familiares. Podendo ser entendido, como o saldo devedor de um indivíduo ou grupo familiar, resultado de uma dívida ou de um conjunto de dívidas. Está relacionado à administração de receitas e despesas, ou seja, corresponde ao percentual da renda que é comprometida com o pagamento de dívidas.

Tolotti (2007) acrescenta que o endividamento ocorre quando um indivíduo não consegue honrar seus compromissos no prazo estabelecido, com atraso entre um e três meses, podendo ser caracterizado como passivo ou ativo.

O endividamento passivo ocorre quando há um aumento de dívidas por consequência de alguma situação alheia à vontade do indivíduo: doença, morte, acidente. São circunstâncias imprevistas e esporádicas. 0 endividamento ativo se caracteriza por um montante de dívidas advindas de escolhas equivocadas, ou seja, má gestão financeira. [...] é considerado sobre endividado o aquele devedor de boa fé que está impossibilitado de pagar suas dívidas de forma durável, ou seja, é o momento em que o indivíduo entra em falência (TOLLOTI, 2007, p 25).

Com crédito fácil e grande oferta no mercado muitas pessoas utilizaram-se dessas facilidades para consumir sem medir o impacto em sua renda mensal, tampouco considerando o peso das parcelas em seu orçamento. Surgiu, então, o problema mais comum decorrente desse tipo de empréstimo, que é o mau uso dos recursos e o elevado endividamento, principalmente das pessoas de baixa renda. 
Consignação dos aposentados e pensionistas: rotinas de pagamento e

desconto em folha

Com o objetivo de minimizar esse problema, o Governo Federal estabeleceu como limite máximo de endividamento $30 \%$ do valor do salário, conforme Instrução Normativa no 37 do INSS, de 02/04/2009, e o Decreto ํo 6.386, de 29/02/2008.

A contratação em massa dos aposentados e pensionistas, sobretudo os de baixa renda e baixo grau de escolaridade, ao crédito consignado fez com que a carteira ganhasse rápida projeção entre os bancos, que passaram a investir massivamente na oferta e publicidade dirigida a esse público. Esses idosos têm se aventurado nesta modalidade de crédito e as sutilezas nesses contratos representam verdadeiras armadilhas para o endividamento: 0 serviço é cedido sem qualquer consulta prévia à saúde financeira do mutuário; dividido em intermináveis parcelas, mantendo a renda comprometida por vários anos; renovado automaticamente, fazendo com que o tomador perca o controle de sua quitação; e liberado por meios que facilitam a ocorrência de fraudes.

O autor Halfeld (2001, p.105) salienta quando é atrativo adquirir dívida, ou seja, tomar crédito para fazer empréstimo ou financiamento:

Para comprar uma mercadoria necessária, cujo preço irá sofrer um substancial aumento nos próximos dias.

Para investir em um negócio, cuja rentabilidade seja bem maior que os juros a serem pagos.

Para pagar outra dívida com taxa de juros superior ao novo empréstimo. Por exemplo, se você deve no cheque especial há muitos dias, pense em obter empréstimos, com juros inferiores, no próprio banco ou em uma financeira.

No cartão de crédito, desde que você quite o saldo devedor no vencimento.

Em uma emergência. Por isso é saudável que mantenha o cadastro atualizado em seu banco.

O consumidor idoso que se torna super endividado está quase sempre imbuído do desejo de satisfazer carências imediatas; atender a pedidos de familiares; ou ainda é mal orientado pelas consignatárias, persuadidos por vendedores abusivos. Contratam o empréstimo 
consignado e rapidamente são engolidos por um turbilhão de consequências por ele não imaginadas que, gradativamente, dificultam o pagamento de suas contas. 0 processo de endividamento culminará na impossibilidade de quitação das dívidas, levando-o à aquisição de novos empréstimos para quitar os anteriores. Este moto-contínuo coloca-o numa situação periclitante, sobretudo quando não mais dispõe de margem consignável para realizar novos empréstimos, embora persista a necessidade de renda extra em razão das dívidas crescentes oriundas de parcelas cada vez mais altas.

Eis o cenário da falência financeira do idoso, ele que já não dispõe do auge de suas forças para se recuperar dos danos causados por este processo, veem afetados gravemente os mais variados aspectos da vida. A vulnerabilidade potencializada, que caracteriza esse consumidor, faz com que o endividamento crônico e excessivo a ele se apresente com feições ainda mais dramáticas.

O Crédito Consignado com desconto em Folha instituído pela Lei o․ 10.820/2003 é tipo de modalidade de empréstimo pessoal para Aposentados, Pensionistas do INSS e Funcionários Públicos Federais, Estaduais e municipais conveniados com Banco e Financeiras com autorização do Banco Central para oferecer este tipo de empréstimo. A Lei n. 10.820/2003, regulamentada pelos Decretos $n . .94 .840 / 2003$ e $n . .95 .892 / 2006$, se refere aos conceitos de remuneração básica, descontos legais, remuneração disponível e descontos voluntários, como elementos de orientação à aplicação dos descontos dos empréstimos consignados (LACERDA e PELUSO, 2008). Segundo os autores, a lei permite ao empregado autorizar de forma irrevogável e irretratável descontos em folha de pagamento e nas verbas rescisórias de prestações de empréstimos, financiamentos e operações de arrendamento mercantil, concedidos por instituições financeiras e sociedades de arrendamento mercantil.

Dada à relevância do tema, crescimento recente da quantidade e do montante das operações de Crédito Consignado com aposentados e pensionistas do INSS, seus reflexos nas políticas públicas do Ministério da Previdência Social, e a reconhecida importância do canal de crédito para o crescimento econômico e o aumento da renda, e a escassez de trabalhos já apontada, faz-se aqui um estudo sobre o crédito consignado do INSS.

A Consignação em folha de pagamento possibilitou que trabalhadores da iniciativa privada, aposentados e pensionistas pelo Instituto Nacional do Seguro Social (INSS) passassem a ter 
acesso à modalidade de Crédito Consignado. Esta inovação colaborou de maneira destacada para impulsionar o crescimento da oferta de crédito pessoal no Brasil.

“O empregador é responsável pelas informações prestadas, pela retenção e repasse dos valores às instituições, até o quinto dia útil após o pagamento do empregado, respondendo sempre como devedor principal e solidário perante a instituição consignatária por valores a ela devidos que deixarem de ser retidos ou repassados por sua falha ou culpa. Não será, porém, corresponsável pelo pagamento dos empréstimos, financiamentos e arrendamentos mercantis concedidos aos mutuários, salvo disposição contratual contrária (LACERDA e PELUSO, 2008)."

A partir de 2001 no próprio mercado de crédito, houve bastante empenho do governo para atender séries de solicitações reprimidas anteriormente, pela situação macroeconômica desfavorável. Mas as melhorias normativas contribuíram extremamente de forma positiva para este mercado tão incipiente à época. Dentre as melhorias, podemos falar como principais: a Lei de Falências, a Lei de Alienação Fiduciária em garantia, desenvolvimento do Crédito Consignado, entre outros.

Suprindo a fragilizada oferta dos bancos privados e com o crescimento da participação dos bancos públicos, aumento da participação de linhas de crédito com menor inadimplência e rearranjo das carteiras dos bancos privados, a inadimplência do sistema aos poucos foi diminuindo, tornando-o mais saudável, reconquistando confiança, tanto das concedentes quanto dos tomadores de crédito.

A possibilidade de consignação com desconto na Folha de Pagamento, com a introdução do consignado, ocasionou a educação do custo dos empréstimos como crédito pessoal à pessoa física e, simultaneamente, permitiu um aumento do prazo possibilitou uma redução expressiva do valor das prestações e, portanto, do comprometimento da renda dos tomadores de crédito.

O Crédito Consignado para Aposentados e Pensionistas do INSS passa por um período de ascensão, onde cresceu em torno de 300\% entre 2006 e 2011 passando de R \$ 7,4 bilhões em 2006 para $R \$ 28,4$ bilhões em 2011, conforme pode ser visualizado na tabela que se 
segue:

Saldo de Operações de Crédito Consignado INSS

\begin{tabular}{|c|c|}
\hline Ano & Valor Consignado INSS (em bilhões de R\$) \\
\hline 2006 & $7.414 .605,00$ \\
\hline 2007 & $15.414 .322,59$ \\
\hline 2008 & $9.017 .403,42$ \\
\hline 2009 & $22.735 .596,40$ \\
\hline 2010 & $26.808 .420,38$ \\
\hline 2011 & $28.408 .280,49$ \\
\hline 2012 & $31.669 .670,71$ \\
\hline 2013 & $41.204 .509,18$ \\
\hline
\end{tabular}

Fonte: MPAS - Ministério da Previdência e Assistência Social.

O crédito consignado visa atender a necessidade desse mercado consumidor aliando baixa burocracia, acesso facilitado e com baixas taxas de juros atendendo as necessidades da terceira idade que está cada vez mais independente.

\section{EMPRÉSTIMOS CONSIGNADOS DE APOSENTADOS E PENSIONISTAS}

Segundo a Ouvidoria Geral da Previdência Social (2005) a norma estabelecida pelo Instituto Nacional de Seguridade Social - INSS permitiu que o crédito consignado não ficasse restrito aos bancos que são autorizados a pagar os benefícios previdenciários. Assim, qualquer banco ou financeira, estabelecendo convênio com o Instituto Nacional de Seguridade Social - INSS e realizando os ajustes do protocolo de troca de informações com a Empresa de Tecnologia e Informações da Previdência Social (Dataprev), pode operar com o Crédito Consignado para os aposentados e pensionistas.

O Crédito Consignado é definido por Barone e Sader (2008, p. 1258) como "um tipo de crédito oferecido para os empregados do setor formal e/ou aposentados e pensionistas do INSS, com baixas taxas de juros [...] em que as prestações são descontadas diretamente de seus salários e/ou aposentadorias e pensões". 
Nesse tipo de empréstimo, além dos juros, é cobrado o Imposto sobre Operações Financeiras (IOF), que incide obrigatoriamente sobre todas as operações de empréstimos realizadas. 0 IOF é um imposto federal que pode ser financiado em conjunto com as parcelas ou deduzido do valor liberado do empréstimo. Não é permitida a cobrança de taxa de abertura de crédito, conforme Instrução Normativa INSS no 5, publicada em 15/05/2006.

A crise econômica fez com que aumentasse ainda mais o número de pessoas a procura de empréstimos consignados, não somente os aposentados e pensionistas, mas também funcionários públicos que também podem optar por este tipo de empréstimo.

Sobre isto Rigo (2007, p. 69) destaca:

Visto que, as transformações mundiais ocorridas ao longo do tempo, influenciaram - Brasil gerando diversas mudanças socioeconômicas, resultantes da globalização, da unificação econômica com liberação dos mercados para importação/exportação e da supervalorização do capital financeiro e especulativo, que são determinantes consideráveis na flexibilização do mercado de trabalho e redução do Estado para a população favorecendo as multinacionais e os bancos.

Rigo (2007) enfatiza sobre o contexto histórico do empréstimo consignado afirmando que:

Para o governo, a iniciativa de estabelecer aprovação para a realização dessas operações, visou ampliar o acesso dos trabalhadores aposentados ou pensionistas ao crédito em condições mais favoráveis, especialmente no tocante à redução das taxas de juros cobradas pelas instituições financeiras. Nesse sentido, deve-se destacar que o desconto das prestações diretamente na folha de pagamento, reduz significativamente o risco de inadimplência nesses empréstimos, fator determinante para a diminuição do spread bancário.

As instituições financeiras que o beneficiário procura para contratar o Crédito Consignado estabelece alguns impedimentos, conferindo dessa maneira, uma maior segurança para o aposentado, que não poderá ter mais de um extrato em atraso, além disso, o aposentado que estiver em gozo de licença não paga pelo INSS não poderá contratar um consignado.

Além da documentação pessoal do aposentado é necessária a atualização cadastral junto ao 
órgão do INSS e comprovante de margem consignável disponível. No caso de aposentados e pensionistas do INSS, para efeito de comprovação de renda, pode ser apresentado somente 0 extrato atual de pagamento do crédito de benefício. A garantia obrigatória é a Cédula de Crédito Bancário - CCB, que nas palavras de Mamede (2010, p.139).

A CCB é um título de crédito que pode ser emitido por pessoa física ou jurídica, na forma cartular (em papel) ou escritural, em favor de uma instituição do Sistema Financeiro Nacional, representando uma promessa de pagamento, em dinheiro, decorrente de operação de crédito de qualquer modalidade. A instituição do Sistema Financeiro Nacional em favor da qual é emitida a CCB é a Instituição Registradora da CCB. Toda vez que alguém contrata um empréstimo com uma instituição financeira, como cartão de crédito, crédito rotativo na conta corrente é emitido contra si uma cédula de crédito bancário. A principal característica da CCB é ser um título executivo extrajudicial, ou seja, não depende do aval do juiz para cobrança, e representa dívida em dinheiro, certa, líquida e exigível, seja pela soma nela indicada. Para tanto, basta que a instituição financeira apresente o saldo devedor demonstrado em planilha de cálculo ou nos extratos da conta corrente elaborados pela Instituição Registradora. Ela é garantida tanto por meios reais quanto por meios fidejussórias constituídas no próprio título. As garantias reais são as que o credor indica um bem do seu patrimônio que sofrerá o ônus no caso de não pagamento do débito. A garantia fidejussória é a garantia pessoal, no caso o aval, quando uma pessoa assegura o pagamento por outra. Somente pode ter uma garantia por título, sendo vedada a cumulação.

O empréstimo consignado pode ser renovado a cada seis meses, sendo que o valor da prestação fica limitado a $30 \%$ (trinta por cento) do valor do benefício. o prazo máximo para a concessão do empréstimo consignado para aposentados e pensionistas do INSS é de 72 meses.

A Instrução Normativa ํo 80 , de agosto de 2015, disciplinando a medida provisória que se refere à alteração da margem consignável nos benefícios previdenciários, destinando um adicional de $5 \%$ para pagamento de despesas referentes ao uso do cartão de crédito. Antes da medida provisória, os beneficiários do INSS dispunham de até 30\% de margem para realização de empréstimos consignados, dividida entre gastos com crédito pessoal e cartão 
de crédito $(20 \%+10 \%$, respectivamente). Quem não utilizava o cartão, poderia comprometer até $30 \%$ da sua renda com o empréstimo pessoal. Com a nova regra, os beneficiários passam a contar com uma margem de consignação de até $35 \%$, mas, agora, $30 \%$ destinados ao crédito pessoal e $5 \%$ para o cartão. A diferença é que esses $5 \%$, independentemente de o usuário utilizá-los ou não com despesas no cartão, não poderão ser adicionados à margem do empréstimo pessoal, cujo teto continua em $30 \%$ do valor da renda mensal.

Afirma-se que existem três tipos de consignados, desta forma, são estes os seguintes:

- Consignação feita diretamente no benefício previdenciário;

- Consignação concedida através do cartão de crédito;

- Consignação feita pelos bancos (O que dá embasamento para a grande concorrência).

\section{METODOLOGIA}

A referida pesquisa terá caráter bibliográfico tendo em vista a grande relevância do estudo desta temática e o considerável número de documentações e obras que abordam este assunto. Dentro desta perspectiva, primeiramente serão pesquisadas as obras por tópico, sendo cada tópico responsável por uma pesquisa, para que no final possam ser separados os autores que mais agradam a temática e assim poder utilizar as suas obras para melhor fundamentar a teoria desta pesquisa.

A localização do material foi realizada a partir dos levantamentos realizados nas bibliotecas de instituições financeiras por assunto, titulo ou autor e em dados disponibilizados via Internet nos sites destas instituições. Inicialmente uma leitura exploratória dos índices dos arquivos, das notas de rodapé, dos abstracts, resumos, introdução e conclusão dos trabalhos, bem como orelhas de livros, permitiram obter uma visão ampla das obras e de sua utilidade para a pesquisa, o que possibilitou sua seleção em função das contribuições que oferecem para o desenvolvimento do tema proposto. Em seguida, o acervo foi reproduzido para posterior leitura com o intuito de identificar as informações relevantes. Sendo assim, e, por passando à análise das informações, preceder-se-á a sua ordenação objetiva.

A leitura exploratória possibilitou maior familiaridade com o tema, permitindo torná-lo mais 
explícito, bem como levar ao aprimoramento de idéias. Desta forma foi possível analisar os fatos do ponto de vista fático e confrontar as diversas visões teóricas com a realidade.

A pesquisa apontou que a maioria solicita o empréstimo para saldar as dívidas em atraso. Se, por um lado, aparenta ser uma alternativa interessante já que as taxas de juros desse tipo de crédito são bem mais baixas, por outro, o consumidor fica com até $30 \%$ do seu benefício comprometido para desconto das parcelas. Considerando-se que a maioria recebe de benefício um salário mínimo e não tem outra fonte de renda, isso pode significar um rombo ainda maior no bolso do consumidor endividado, caso não faça a contratação de forma consciente.

\section{ANALISE DA PESQUISA}

Através da análise do gráfico abaixo é possível compreender quais os motivos que levaram os aposentados e pensionistas a adquirirem o Empréstimo Consignado.

Motivos para aquisição do Crédito Consignado 


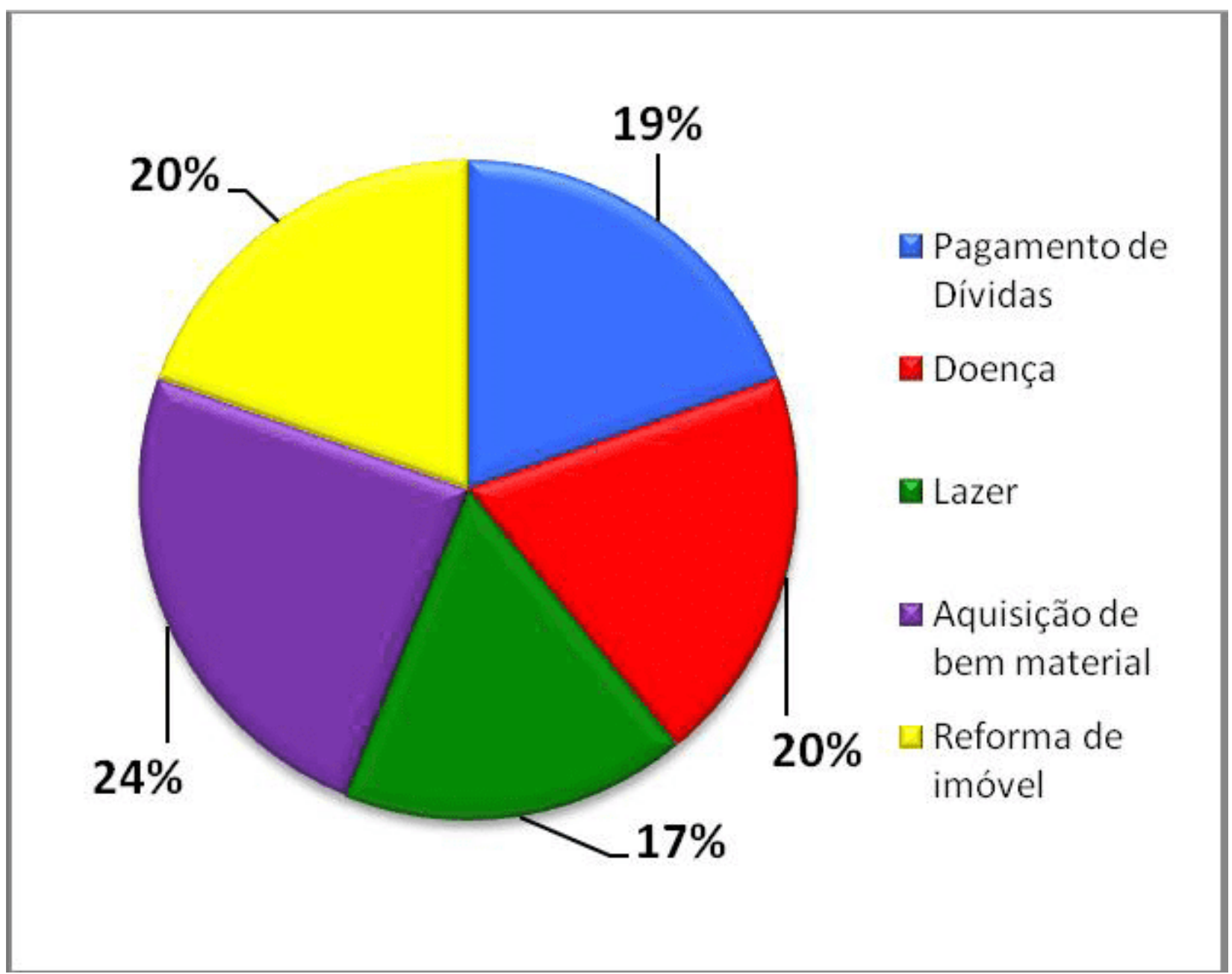

Fonte: Gráfico construído de acordo com os resultados obtidos através da pesquisa de campo (2014)

Pode-se constatar que inicialmente o motivo que impulsiona os aposentados e pensionistas a contrair o Crédito Consignado é a aquisição de bem material, de modo que $24 \%$ alegaram ser este o fator mais relevante. Em seguida 40 \% deles afirmaram que o motivo que os levaram a adquirir o empréstimo foram respectivamente reforma de imóvel e doença, sendo que cada um desses motivos obteve $20 \%$, Posteriormente $19 \%$ citaram o pagamento de dívidas como motivo.

\section{CONSIDERAÇÕES FINAIS}

Uma modalidade de crédito que vem crescendo expressivamente nos últimos anos, devido 
ao baixo risco de inadimplência e facilidade de análise e aprovação. Já o perfil do cliente é composto principalmente mulheres que solicitam esse tipo de crédito para quitar dívidas, o que demonstrando de um lado, as necessidades dos aposentados brasileiros para atender suas necessidades financeiras. Revela ainda que, os requisitantes do crédito dependem de recursos pessoais e de recursos de terceiros, em especial, dos empréstimos bancários para manter um determinado padrão de vida.

O Crédito Consignado de um Benefício e considerado uma vantagem quando planejado e utilizado de maneira correta, pois são utilizados por pessoas na maioria das vezes de baixa renda, motivados a realizar o crédito para adquirir bens e pagar outros compromissos.

Ao analisar os clientes que contrataram o Crédito Consignado observa-se que a media comprometida e alta, chegando próximo à margem máxima de $30 \%$, sendo que em media um cliente possui mais de duas operações ativas. Também e necessário considerar que este comprometimento pode ser ainda maior, uma vez que além do Crédito Consignado estes clientes também possuem as outras linhas de créditos disponíveis.

Considerando o total de benefícios consignáveis pagos na instituição, observa que o maior percentual de clientes não tem sua renda comprometida com esta linha de credito. Apesar disso não se pode afirmar que esses clientes possuem a renda livre de comprometimento, uma vez que existem inúmeras outras opções de crédito que não foram observadas neste estudo.

Concluímos que existem diversos fatores sociais que se relacionam com o Crédito Consignado e citamos na pesquisa; situação familiar, situação econômica, motivo da aposentadoria, usufruto do empréstimo, valores e números de empréstimos efetuados pelos idosos, vantagens e desvantagens da operação.

\section{REFERÊNCIAS}

BARONE, F. M.; SADER, E. Acesso ao crédito no Brasil: evolução e perspectivas. Revista de Administração Pública, 2008.
BANCO
D O
BRASIL.
Credito.
Disponível
e m : 
Consignação dos aposentados e pensionistas: rotinas de pagamento e

desconto em folha

HTTP://www.bb.com.br/portalbb/page251,8900,8923,0,01,0.b.b?codigoMenu=5415\&codigoN oticia $=81$ 33. Acesso em: 10 de maio 2016.

CASTANHEIRA, Nelson Pereira. MACEDO, Luiz Roberto Dias de. Matemática Financeira Aplicada. São Paulo: Editora Ibpex, 2008.

DAL RI, Marlene K Conteúdo da disciplina de Finanças e Mercado de Capitais. Curso de Economia. Ijuí, RS: Ed. da Unijuí, 2009a.

HALFELD, M. Investimentos: Como administrar melhor seu dinheiro. 1a ed. São Paulo: Editora Fundamento Educacional, 2001.

Instrução normativa INSS/PRES № 28, de 16 de maio de 2008 - D.O.U de 19/05/2008. Estabelece critérios e procedimentos operacionais relativos à consignação de descontos para pagamento de empréstimos e cartão de crédito, contraídos nos benefícios da Previdência Social. Brasília, Senado, 2014.

LACERDA, Nadia D.; PELUSSO, José Ubirajara. Empréstimo consignado e descontos legais. Paraná on line. 19/07/2008.

MAMEDE, Gladston. Direito Empresarial Brasileiro. São Paulo: Atlas, 2010.

MOREIRA, José dos Santos. Matemática comercial e financeira. São Paulo: Atlas, 1967.

RIGO, JULIANA R. EMPRÉSTIMO CONSIGNADO: repercussões sociais relacionadas a vida dos idosos do município de palhoça de Palhoça/SC. Florianópolis, fev, 2007.

SANDRONI, Paulo. Novíssimo Dicionário de economia. São Paulo: Best Seller, 1999.

TOLOTTI, Márcia. As Armadilhas do Consumo: acabe com o endividamento. Rio de Janeiro, RJ. Elsevier, 2007.

https://www.consignados.com.br/duvidas/sem-margem-para-emprestimo-consignado/. Acesso em: Novembro, 2017. 
Consignação dos aposentados e pensionistas: rotinas de pagamento e desconto em folha

http://www.previdencia.gov.br/2017/03/consignado-taxas-de-juros-nos-emprestimos-consigna dos-para-servidores-aposentados-e-pensionistas-tem-queda/. Acesso em: Novembro, 2017.

http://www.prosiga.net/2013/07/novas-regras-para-emprestimos-do-inss.html/. Acesso em: Novembro, 2017.

http://www.webartigos.com/artigos/emprestimo-consignado-por-meio-de-retencao/116206/. Acesso em: Novembro, 2017.

${ }^{[1]}$ Graduanda do Curso de Ciências Contábeis da Faculdade de Rondônia - FARO.

${ }^{[2]}$ Professora orientadora do Curso de Ciências Contábeis da Faculdade de Rondônia - FARO.

Enviado: Junho, 2018

Aprovado: Maio, 2019. 